\title{
QUALITY OF LIFE OF ELDERS IN THE PRIMARY HEALTH CARE IN UBERABA, MG
}

\author{
QUALIDADE DE VIDA DE IDOSOS DA ATENÇÃO PRIMÁRIA À SAÚDE EM \\ UBERABA, $M G$
}

\section{Giovanna Gaudenci NARDELLI ${ }^{1}$; Eliana Maria GAUDENCI ${ }^{2}$; Rodrigo Eurípedes da SILVEIRA ${ }^{3}$; Álvaro da Silva SANTOS ${ }^{4}$; Camila Cristina Neves Romanato RIBEIRO ${ }^{5}$; Karla Rafaela HAACK ${ }^{6}$}

1. Enfermeira. Mestre em Atenção à Saúde. Doutoranda em Atenção à Saúde. Professor Assistente - Departamento de Saúde Coletiva Universidade Federal do Triângulo Mineiro - UFTM. Giovanna.gnardelli@gmail.com; 2. Enfermeira. Mestre em Atenção à Saúde. Doutoranda em Atenção à Saúde. Enfermeira na Secretaria Municipal de Saúde da Prefeitura Municipal de Uberaba SMS/PMU; 3. Enfermeiro. Mestre em Ciências da Saúde. Doutorando em Ciências pela Coordenadoria de Controle de Doenças da Secretaria de Estado de Saúde de São Paulo. Professor Assistente - Departamento de Saúde Coletiva da UFTM; 4. Enfermeiro. Especialista em Saúde Pública. Mestre em Administração em Serviços de Saúde. Doutor em Ciências Sociais. Pós Doutorado em Serviço Social. Professor Associado de Graduação e da Pós Graduação Estrito Senso em Atenção à Saúde da UFTM. alvaroenf@hotmail.com; 5. Enfermeira. Mestre em Atenção à Saúde. Doutoranda em Atenção à Saúde pela UFTM; 6. Psicóloga. Mestra e Doutora em Psicologia Clínica pela Universidade do Vale do Rio dos Sinos (UNISINOS). Docente do curso de Psicologia das Faculdades Integradas de Taquara (FACCAT).

\begin{abstract}
This study aimed to evaluate social and economic predictors, as well social behavior and its influence on the quality of life of elders who use the primary health care network of Uberaba, Minas Gerais. Methods: Descriptive, exploratory, cross-sectional and quantitative study, conducted with 24860 year old or older subjects, from November 2016 to May 2017. A structured questionnaire was applied to evaluate sociodemographic data, health conditions and life habits as well the WHOQOL-Bref and the WHOQOL-Old. The analysis were conducted through relative frequencies and t-test as well multiple linear regression were used to associate variables. The study was approved by the Committee of Ethics in Researches with Human Beings of the Federal University of the Triângulo Mineiro (CEP/UFTM). Results: Most elders were women, catholic, with 4 years or more of formal education, had partners, a sexually inactive life, and were retired. The linear regression analysis, found a positive and light or moderate association between sexual life and the physical, social, and environmental domains, and the past, present and future activities facet. The educational level variable had a positive and light association with the psychological domain, whereas the variable occupation had a negative and light association with the death and dying facet. Conclusions: The results found show an important social impact regarding the studied population, making it clear that public policies should be created and executed as to offer subsidies for actions which are specifically targeted at the QoL of elders.
\end{abstract}

KEYWORDS: Quality of Life. Aged. Eldery health. Primary Health Care.

\section{INTRODUCTION}

In the last decades, a growth in population aging has been observed throughout the world to an increase in the life expectancy of the population. This phenomenon has called the attention of professionals from many fields of knowledge, are concerned with the social, economic, health and well-being related consequences it can bring to the individual that is going through the process (SILVEIRA et al., 2015).

In Brazil, the number of elders doubled in the last 20 years, to a total of 23.5 million people, most of whom have a low socio-economic and educational level and a high prevalence of chronic and disabling diseases, which reflects the fact that aging brings about an increase in the limitations and a decline in health. However, recent studies have indicated that most elders can independently perform daily life activities, even if they do not practice exercise (SANTOS et al., 2015).

Therefore, the importance of establishing better social policies that generate better health conditions and well-being for the individual needs to be considered, leading to a "process of optimizing health opportunities, participation and safety, to improve quality of life as people grow older" (THE CANADIAN MEDICAL ASSOCIATION, 2013).

Quality of life (QoL) is a construct whose definition is influenced by cultural, ethical, religious and personal aspects, and is related to individual perception. According to the World Health Organization, it is "a perception of the individual, regarding their position in life in the context of the 
Quality of life...

culture and value systems in which they live and of their relationship with their own objectives, expectancies, standards and preoccupations" (FLECK; CHACHAMOVICH; TRENTINI, 2006).

Considering the multidimensional aspect of QoL, which involves subject parameters such as well-being, happiness, and personal conquests, and objective parameters, such as the satisfaction of basic needs and of those that emerge from the social structure available, the perception regarding that of the elders is strongly associated to their health, including references to the importance of positive feelings, personal relationships, and good nutrition. Thus, the higher the number of morbidities, the smaller the scores of QoL perception (FLECK; CHACHAMOVICH; TRENTINI, 2006; PASKULIN et al., 2010).

Although the theme is very popular in discussions of future public policies, one needs to consider the scarcity of studies that include community elders, and that use instruments created for this population to identify their real needs and delineate plans of action for public health and social security services to meet these demands. From this perspective, this study aimed to evaluate social and economic predictors, as well as social behavior when it comes to its influence on the quality of life of elders who use the primary health care network.

\section{MATERAL AND METHODS}

This is a descriptive, exploratory, crosssectional and quantitative study, which is part of a larger project called "Quality of life and profile of elders in the Primary Health Care of a municipality in the countryside of Minas Gerais". It involved 248 elders (60 years old or older), registered in the Primary Health Care Units of the city of Uberaba, MG, whose cognitive functions were satisfactory according to the results of a Mini-Mental State Examination (MMSE), applied according to their educational level.

The psychological domain of the WHOQOL-Bref instrument was considered to be one of the dependent variables for the calculation of the size of the sample, with a determination coefficient of $\mathrm{R}^{2}=0.10$ in a model of multiple linear regression with seven predictors and a level of significance $(p)$ of 0.01 , beta error of 0.1 , and statistical power of $90 \%$. The minimum sample size of 228 interviews was found through the PASS (Power Analysis and Sample Size) software, version 14 , and $20 \%$ was added to that number to compensate for sample losses, to a total of 273 elders.
NARDELLI, G. G. et al.

Convenience led the selection of the sample and the collection was conducted by a trained team, from November 2016 to May 2017. The following instruments were used: a questionnaire with sociodemographic data, health conditions and life habits; the WHOQOL-Bref; and the WHOQOLOld.

The study respected all the formal demands included in the national and international norms that regulate researches involving human beings, and was approved by the Research Ethics Committee of the Universidade Federal do Triângulo Mineiro (UFTM) under protocol 1.604.573.

Data from the questionnaires were typed double input on the Microsoft Excel ${ }^{\circledR}$ software, by different people, and then transported to the software Statistical Package for Social Sciences (SPSS), 20.0.

For the exploratory analysis of the data, absolute (n) and relative (\%) frequencies were calculated, as well as measures of central tendency (average) and dispersion (standard deviation), considering the variables that are relevant for the characterization of the elders who participated in the study. For the correlation between the perception of quality of life and the sociodemographic variables, the t-test was used for independent samples, with a significance level of $0.01(p \leq 0.01)$.

To confirm the connection between the predictors and QoL, a multiple linear regression was conducted, using six predictors chosen according to the literature. In addition, all pre-requisites for the use of the regression model, such as residue analysis, atypical numbers and multicollinearity, were considered.

\section{RESULTS}

248 elders participated in the study, all of which were registered in the Primary Health Care Units of the city of Uberaba, MG, and had satisfactory cognitive functions as indicated by the results of a Mini-Mental State Examination (MMSE), applied according to their educational level.

In the variable gender, $68.5 \%(\mathrm{n}=170)$ of the participants were women, and $31.5 \%$, men. The mean age was 68.5 years $(\mathrm{SD}=6,52)$, where $92.3 \%$ had 60 to 79 years and $7.7 \% 80$ years or more. Regarding religion, $63.3 \%(\mathrm{n}=157)$ of participants were catholic, followed by the evangelic and spiritualists, who, respectively, represented $14.9 \%$ $(\mathrm{n}=37)$ and $10.9 \%(\mathrm{n}=27)$ participants.

Regarding the educational level of the participants, results have shown that $47.2 \%(n=117)$ 
had studied for 4 years or more, 37.9\% ( $\mathrm{n}=94)$ studied had studied between 1 and 3 years and $13.3 \%$ of the elders $(n=33)$ had no formal education at all. Only $14.1 \%(n=45)$ had studied for more than 8 years.

Concerning the variable "have a partner", $52.4 \%(\mathrm{n}=130)$ answered that they do have one, while $47.3 \%(n=117)$ did not. Regarding income, most $(89.1 \% ; n=222)$ participants had a monthly income that varied from 1 to 3 minimum wages, while $5.6 \%(n=14)$ had an income of 4 minimum wages or more per month. It stands out that 115
(46.4\%) of the elders have a monthly income of up to one minimum wage.

Concerning questions about their sexual lives, $68.9 \%(\mathrm{n}=173)$ of the elders stated not to enjoy a sexually active life, whereas $27.8 \%(n=69)$ stated that they did.

Regarding their professional lives and occupation, $62.9 \%(\mathrm{n}=156)$ of the elders are retired, $13.3 \%(n=33)$ work, $16 \%(n=47)$ are housewives, and $4.4 \% \quad(n=11)$ indicated other types of occupation, and one did not answered (Table 1).

Table 1. Sociodemographic variables of the elderly users of primary health care - Uberaba/MG, 2017.

\begin{tabular}{lcc}
\hline Variables & $\mathrm{n}$ & $\%$ \\
\hline Gender & 170 & 68.5 \\
Female & 78 & 31.5 \\
Male & & 78.2 \\
Religion & 194 & 16.5 \\
Catholic or Protestant & 41 & 13.3 \\
Other & & 37.9 \\
Education & 33 & 47.2 \\
None & 94 & 47.2 \\
From 1 to 3 years old & 117 & 52.4 \\
4 years or more & & \\
Partner & 117 & 89.1 \\
No & 130 & 5.6 \\
Yes & & \\
Income & 222 & 27.8 \\
Up to 3 MW & 14 & 68.9 \\
4 MW or more & & \\
Sexually active life & 69 & 62.9 \\
Yes & 173 & 13.3 \\
No & & 16 \\
Occupation & 156 & 4.4 \\
Retired & 33 & \\
Works & 47 & \\
Housewives & 11 & \\
Other & & \\
\hline Sorce teats & & \\
\hline
\end{tabular}

Source: the authors, 2017.

A bivariate analysis between the WHOQOL-Bref domains and the sociodemographic variables has shown that, regarding gender, the domain with the highest averages, for both females and males, was the psychological domain, with 65.3 $(\mathrm{DP}=18.2)$ and $71.8(\mathrm{DP}=15.1)$, respectively. The highest averages for both genders were in the environment domain, 57.2 (DP=12.6) among women and $61.1(\mathrm{DP}=13.2)$ among men. In spite of that, there was an association between the genders and the psychological and environment domains. The perception of QoL for the females was lower in the psychological domain than that of the male elders, and the same result was found regarding the perception of the participants in the environment domain.

When the domains were analyzed regarding educational levels, there were statistically significant links between a lower education (up to 3 years $)$ and the psychological $(x=63.8 ; \mathrm{DP}=17.9)$ and social $(x=62.6 ; \mathrm{DP}=18.7)$ domains. Therefore, the lowest educational level leads to a diminution in the perception of these domains.

The variable income was associated to the physical domain, pointing out that the lowest the income, the lowest the perception for this domain among the respondents. 
There was an association between all the domains of the WHOQOL-Bref and an active sexual life, indicating that sexually inactive elders have a worse perception of the QoL in all its domains.
There was a relationship between occupation and the physical domain, and therefore, data demonstrates that the least active elders have a lower perception of the QoL in this domain (Table 2).

Table 2. Results of the bivariate analysis of the predictors and of the WHOQOL-Bref - Uberaba/MG, 2017.

\begin{tabular}{|c|c|c|c|c|c|c|c|c|}
\hline & \multicolumn{2}{|c|}{ PHYSICAL } & \multicolumn{2}{|c|}{ PSYCHOLOGICAL } & \multicolumn{2}{|c|}{ SOCIAL } & \multicolumn{2}{|c|}{ ENVIRONMENT } \\
\hline & $\mathrm{X}$ & SD & $\mathrm{X}$ & SD & $\mathrm{X}$ & SD & $\mathrm{X}$ & SD \\
\hline \multicolumn{9}{|l|}{ Gender } \\
\hline Female & 59.8 & 17.3 & 65.3 & 18.2 & 64.7 & 18.4 & 57.2 & 12.6 \\
\hline Male & 65.1 & 16.2 & 71.8 & 15.1 & 66.1 & 18.3 & 61.6 & 13.2 \\
\hline \multicolumn{9}{|l|}{ Religion } \\
\hline Catholic or & 60.2 & 16.6 & 66.5 & 17.8 & 65.1 & 18.0 & 57.9 & 12.5 \\
\hline \multicolumn{9}{|l|}{ Protestant } \\
\hline \multicolumn{9}{|l|}{ Education } \\
\hline $\begin{array}{l}3 \text { years study or } \\
\text { less }\end{array}$ & 59.1 & 16.8 & 63.8 & 17.9 & 62.6 & 18.7 & 58.3 & 12.5 \\
\hline \multicolumn{8}{|l|}{ Partner } & 13.3 \\
\hline No & 60.8 & 16.0 & 67.7 & 16.8 & 62.3 & 19.4 & 57.8 & 12.8 \\
\hline Yes & 61.4 & 18.0 & 67.0 & 18.2 & 68.0 & 16.6 & 59.4 & 12.9 \\
\hline \multicolumn{9}{|l|}{ Income } \\
\hline Up to $3 \mathrm{MW}$ & 60.2 & 17.1 & 66.8 & 17.8 & 64.8 & 18.4 & 58.0 & 12.9 \\
\hline $4 \mathrm{MW}$ or more & 73.5 & 12.4 & 75.6 & 10.7 & 69.6 & 12.5 & 63.4 & 11.2 \\
\hline \multicolumn{9}{|l|}{ Sexually active } \\
\hline \multicolumn{9}{|l|}{ life } \\
\hline No & 58.2 & 16.6 & 65.2 & 18.0 & 61.9 & 17.9 & 56.9 & 12.4 \\
\hline Yes & 67.8 & 16.6 & 71.8 & 15.5 & 74.3 & 16.1 & 62.5 & 12.9 \\
\hline \multicolumn{9}{|l|}{ Occupation } \\
\hline Less active & 59.2 & 17.3 & 66.4 & 18.1 & 65.2 & 17.9 & 58.6 & 12.8 \\
\hline More active & 69.6 & 13.2 & 71.6 & 14.1 & 65.7 & 19.8 & 58.9 & 13.0 \\
\hline \multicolumn{9}{|l|}{ Age } \\
\hline $60-79$ years & 61.4 & 17.4 & 66.9 & 17.4 & 65.2 & 18.5 & 58.4 & 10.7 \\
\hline 80 or older & 58.8 & 14.7 & 71.7 & 18.7 & 63.6 & 16.9 & 60.2 & 17.2 \\
\hline
\end{tabular}

Source: the authors, 2017. Highlights: results lower or equal to 0.01 .

The bivariate analysis of the sociodemographic variables and the facets of the WHOQOL-Old showed statistically significant results between many facets. There was an association between the catholic or protestant religion and the death and dying facet, it being found that elders who were catholic or protestant had a worse perception of QoL. Low educational levels had an association with the sensory function facet, and not having a partner presented a relation with the intimacy facet. The lack of a sexual life was significantly related to the facets "past, present and future activities", "social participation", "intimacy", and "sensory function". Significant results were also found for the variables "less occupationally active" and "age", when considering elders over 80 years old (Table 3 ).

A linear regression analysis, adapted to the predictors, the WHOQOL-Bref domains and the WHOQOL-Old facets, found a positive and light ( $\beta$ $=0.2)$ or moderate $(\beta=0.3)$ association between sexual life and the physical, social, and environmental domain, and the facet "past, present and future activities". The educational level variable had a positive and light $(\beta=0,2)$ association with the psychological domain, while the occupation variable was found to have a negative and light $(\beta=$ $0,2)$ association to the facet death and dying (Table $4)$. 
Table 3. Results of the bivariate analysis between the predictors and the facets of the WHOQOL-Bref Uberaba/MG, 2017.

\begin{tabular}{|c|c|c|c|c|c|c|c|c|c|c|c|c|}
\hline & \multicolumn{2}{|c|}{ Autonomy } & \multicolumn{2}{|c|}{$\begin{array}{l}\text { Past, Present, } \\
\text { and Future } \\
\text { Activities }\end{array}$} & \multicolumn{2}{|c|}{$\begin{array}{l}\text { Social } \\
\text { Participation }\end{array}$} & \multicolumn{2}{|c|}{$\begin{array}{l}\text { Death and } \\
\text { Dying }\end{array}$} & \multicolumn{2}{|c|}{ Intimacy } & \multicolumn{2}{|c|}{$\begin{array}{l}\text { Sensory } \\
\text { Function }\end{array}$} \\
\hline & $X$ & SD & $X$ & SD & $X$ & SD & $\mathrm{X}$ & SD & $X$ & SD & $X$ & SD \\
\hline Gender & & & & & & & & & & & & \\
\hline Female & 64.9 & 18.5 & 65.1 & 17.5 & 62.0 & 17.3 & 62.9 & 27.4 & 67.4 & 22.0 & 65.5 & 24.6 \\
\hline Male & 67.3 & 14.7 & 68.5 & 14.3 & 62.7 & 17.1 & 64.8 & 28.6 & 71.0 & 19.6 & 68.4 & 23.9 \\
\hline Religion & & & & & & & & & & & & \\
\hline $\begin{array}{l}\text { Catholic or } \\
\text { Protestant }\end{array}$ & 65.3 & 17.6 & 66.6 & 16.4 & 62.2 & 16.6 & 60.7 & 27.7 & 68.4 & 21.6 & 66.4 & 24.6 \\
\hline $\begin{array}{l}\text { Other } \\
\text { Education }\end{array}$ & 69.0 & 17.1 & 66.9 & 17.6 & 63.7 & 19.7 & 74.0 & 27.1 & 67.0 & 20.3 & 68.6 & 21.7 \\
\hline $\begin{array}{l}3 \text { years } \\
\text { study or less }\end{array}$ & 63.9 & 18.6 & 65.8 & 16.8 & 62.2 & 17.3 & 63.1 & 26.6 & 65.6 & 22.7 & 60.6 & 24.3 \\
\hline $\begin{array}{l}4 \text { years or } \\
\text { more }\end{array}$ & 68.2 & 15.6 & 67.1 & 16.5 & 62.7 & 17.3 & 64.3 & 29.0 & 71.9 & 19.4 & 72.8 & 22.9 \\
\hline Partner & & & & & & & & & & & & \\
\hline No & 66.9 & 17.5 & 65.3 & 18.4 & 61.1 & 17.6 & 64.7 & 26.5 & 64.2 & 21.1 & 66.2 & 23.0 \\
\hline Yes & 64.9 & 17.0 & 67.1 & 14.7 & 63.5 & 16.8 & 62.1 & 28.9 & 72.6 & 20.8 & 66.5 & 25.6 \\
\hline Income & & & & & & & & & & & & \\
\hline $\mathrm{Up}$ to $3 \mathrm{MW}$ & 65.6 & 17.3 & 66.0 & 18.8 & 62.2 & 17.3 & 62.1 & 28.1 & 68.2 & 21.2 & 65.3 & 24.5 \\
\hline $\begin{array}{l}4 \mathrm{MW} \text { or } \\
\text { more }\end{array}$ & 69.2 & 11.0 & 63.5 & 11.4 & 58.7 & 16.7 & 72.6 & 23.6 & 73.6 & 14.7 & 78.4 & 21.8 \\
\hline $\begin{array}{l}\text { Sexually } \\
\text { active life }\end{array}$ & & & & & & & & & & & & \\
\hline No & 64.8 & 17.8 & 64.2 & 16.8 & 60.4 & 16.8 & 62.3 & 27.1 & 64.6 & 21.1 & 63.1 & 24.6 \\
\hline Yes & 68.0 & 15.4 & 71.2 & 14.4 & 66.6 & 17.3 & 65.0 & 29.1 & 79.0 & 19.0 & 73.6 & 22.3 \\
\hline Occupation & & & & & & & & & & & & \\
\hline Less active & 64.4 & 17.6 & 66.8 & 16.4 & 62.0 & 17.2 & 64.6 & 26.5 & 68.3 & 21.2 & 65.2 & 24.3 \\
\hline More active & 72.7 & 14.0 & 63.7 & 17.2 & 64.1 & 17.4 & 57.4 & 32.6 & 69.9 & 22.0 & 72.0 & 24.6 \\
\hline Age group & & & & & & & & & & & & \\
\hline 60-79 years & 66.3 & 17.2 & 66.0 & 17.0 & 62.3 & 17.5 & 62.3 & 27.9 & 68.1 & 21.5 & 66.8 & 24.4 \\
\hline 80 or older & 57.9 & 18.3 & 68.1 & 11.8 & 61.8 & 14.0 & 77.3 & 21.4 & 73.4 & 18.3 & 61.8 & 24.3 \\
\hline
\end{tabular}

Table 4. Multiple linear regression analysis between the predictors and the domains and facets of the quality of life. Uberaba/MG, 2017.

\begin{tabular}{|c|c|c|c|c|c|c|c|c|c|c|c|c|}
\hline & \multicolumn{2}{|c|}{ Gender } & \multicolumn{2}{|c|}{ Sexual life } & \multicolumn{2}{|c|}{ Education } & \multicolumn{2}{|l|}{ Income } & \multicolumn{2}{|c|}{ Occupation } & \multicolumn{2}{|c|}{ Age Group } \\
\hline & $\mathrm{B}$ & $\mathrm{p}$ & B & $\mathrm{P}$ & $\mathrm{B}$ & $\mathrm{P}$ & $\beta$ & $\mathrm{P}$ & $\mathrm{B}$ & $\mathrm{P}$ & B & $\mathrm{P}$ \\
\hline Physical & 0.08 & 0.2 & 0.2 & 0.01 & 0.5 & 0.4 & 0.1 & 0.1 & 0.1 & 0.07 & 0.01 & 0.9 \\
\hline Psychological & 0.1 & 0.05 & 0.1 & 0.2 & 0.2 & 0.001 & 0.06 & 0.4 & 0.02 & 0.8 & 0.1 & 0.07 \\
\hline Social & -0.03 & 0.6 & 0.3 & $<0.001$ & 0.1 & 0.1 & 0.02 & 0.8 & -0.07 & 0.3 & 0.2 & 0.7 \\
\hline Environment & 0.1 & 0.1 & 0.2 & 0.01 & 0.009 & 0.9 & 0.08 & 0.2 & -0.07 & 0.3 & 0.06 & 0.4 \\
\hline Autonomy & 0.05 & 0.5 & 0.05 & 0.5 & 0.08 & 0.2 & -0.01 & 0.9 & 0.1 & 0.05 & -0.1 & 0.1 \\
\hline Activities & 0.07 & 0.3 & 0.2 & 0.004 & 0.04 & 0.5 & -0.04 & 0.5 & -0.2 & 0.7 & 0.05 & 0.4 \\
\hline $\begin{array}{l}\text { Social } \\
\text { Participation }\end{array}$ & -0.03 & 0.7 & 0.2 & 0.02 & -0.005 & 0.9 & -0.08 & 0.3 & 0.03 & 0.6 & 0.03 & 0.7 \\
\hline $\begin{array}{l}\text { Death and } \\
\text { Dying }\end{array}$ & 0.02 & 0.7 & 0.05 & 0.4 & 0.04 & 0.6 & 0.1 & 0.08 & -0.2 & 0.01 & 0.1 & 0.03 \\
\hline Intimacy & -0.01 & 0.8 & 0.3 & $<0.001$ & 0.1 & 0.03 & -0.001 & 0.9 & 0.007 & 0.9 & 0.1 & 0.04 \\
\hline $\begin{array}{l}\text { Sensory } \\
\text { Function }\end{array}$ & 0.009 & 0.9 & 0.2 & 0.03 & 0.2 & 0.003 & 0.08 & 0.2 & -0.01 & 0.8 & $-\overline{0.003}$ & 0.9 \\
\hline
\end{tabular}

Source: the authors, 2017. Highlights: results lower or equal to 0.01 . 


\section{DISCUSSION}

As age advances, there is an improvement in chronic conditions and functional changes that result in physical, emotional and/or psychological compromise; consequently, the advance of age may diminish the perception of health and QoL. Health perception has been especially worthy of attention, as it has been described as an index of the decline of functional autonomy and even of mortality among elders, having as such the potential to synthesize a complex interaction of factors involved in their health. In addition, the study of life conditions and social aspects of the elder can offer notions of how health systems can be more effective and efficient (SILVA et al., 2012).

The prevalence of women in the sample of the study is a characteristic found in other Brazilian studies (FLECK, 2000; GAMPEL; KARSH; FERREIRA, 2010; DOS SANTOS et al., 2015) about the quality of life of elders. Female elders are considered to participate more in socialization groups and non-domestic activities than their male counterparts, and the number of women is higher in urban areas (SILVEIRA et al., 2015; SANTOS et al., 2014).Tavares and Dias (2012) found that women live approximately seven years more than men, and present more chronic and disabling health problems, while men develop more short-term and/or fatal diseases.

The low educational and socio-economic levels were convergent with those found by the national scientific literature. Confronted with these evidences, it can be found that the socioeconomic conditions - such as poor residences, economic dependency or financial instability, directly contribute to a negative perception of health among the elders. Corroborating this finding, Lima-Costa et al. analyzed data from the National Research of Sample by Residence, from 1998, conducted with nearly 20 thousand Brazilian elders, and found that those with the lowest domiciliary income had a lower health perception than those with better financial conditions (LIMA-COSTA et al., 2003).

To identify the social representations of older adults regarding quality of life in Rio de Janeiro, Ferreira et al. (2017) used the software Alceste and lexical analysis of data. As results were found that social representations of quality of life are based on the social determinants of health; they evidence knowledge and practices of care by valuing physical activities. The practices promoting quality of life comprise healthy eating habits, daily physical exercise, social participation, interaction and socialization, accomplishment of leisure activities and daily tasks with independence and autonomy, and support and family contact. Thus, aged people have a global understanding of the concept of quality of life, coordinate knowledge built in daily life and knowledge coming from the technical-professional field, which evidences the multidimensionality of the concept.

Therefore, public policies for health promotion among elders should seek additional tools to contribute for a better QoL and health in the low-income subgroup. These intervention actions not only stimulate the practice of physical activity and social relationships, but also promote an environment with better structural conditions (for example, access to healthy food, good hygiene conditions and educational activities), both in and out of the activity centers. For these actions to be conducted, the creation of new programs with a multi-disciplinary focus is important, so several different aspects of the lives of individuals can be involved, thus offering better life conditions, and possibly, better QoL and health. Thus, the development of specific actions for this risk subgroup can contribute for the promotion of health and QoL in the Brazilian elder population as a whole (RODRIGUES et al., 2017).

Regarding religion, the catholic religion, followed by the evangelic and spiritualism, were the most common, which is in accordance to the literature (PILGER, 2016). A recent study has shown an association between the dimensions of the quality of life related to the health of elders and the different levels of religiosity: organizational, nonorganizational and intrinsic. It was also found that the use of religiosity as a therapeutic device is compatible with the physical and mental health of the elder, allowing them to have a better quality of life (SANTOS; ABDALA, 2012).

Meaningful results were observed regarding sexual activities and the domains of the questionnaires. Society often ignores that the changes that happen as a result of the aging process do not prevent the elders from living sexuality as a part of a natural process. In a Group for Senior Citizens, with the participation of 15 elder women, it was found that all the participants continue to be interested in sexual relations, and when sexual activity was absent, dating and partner relationships were indicated as substituted for sex. Another aspect considered by the elders concerns physical beauty, which is connected to youth, meaning they do not feel attractive enough to have sexual intercourse due to their advanced age (COELHO et al., 2010).

The stable presence of a sexual partner is reported as a positive aspect for the continuity of 
sexual relations. It can, however, contribute to the sexual abstinence of women, if one considers the possibility that they become widows. Among men, the reaction is different, as some elders look for other partners, mostly young ones, to continue having sexual activities (COELHO et al., 2010). When there is a sexual partner, the desire to keep sexual activities remained for $75 \%$ of the elders, a total of 162 participants. When there is no stable partner, however, a significant decline in sexual relations is found, and only $14.3 \%$ report to still have sexual desires (FERREIRA et al., 2009).

The psychological domain had the highest average and the environmental domain the lowest one, corroborating a study by Almeida-Brasil (2017). The psychological domain indicates that elders have good cognitive abilities (thinking, learning and focusing), spirituality and religion, and acceptance of their physical appearance while keeping a high self-esteem. The environment domain, however, involves questions regarding financial resources, physical safety and protection, opportunities for leisure and recreation, physical environment and access to means of transportantion (SILVA et al., 2012).

The highest perception of QoL found was in the intimacy facet, the same found in the research conducted by Pilger (2016). The lowest one was in the social participation facet, which can indicate that the individuals receive less support from the family and the friends than they hoped for. Such a finding is also supported by the literature, for which a lower score in social participation is an index of less opportunities to participate in community activities. Thus, it is necessary for health services to identify the options of community activities, as well as the interest of the elders, to minimize negative impacts on this facet.

The sociodemographic variables that were shown to influence, in the bivariate analysis, the physical domain of the WHOQOL-Bref, were income and occupation. Lower income and activity had the lowest averages in the perception of QoL. The psychological domain was influenced by gender and educational level, the female gender and an educational level below four years of study presenting the lowest averages. One of the possible reasons for this result is that, possibly, women see aging as a more negative factor (ALMEIDABRASIL et al., 2017). In addition, the fact that elder women are more predisposed to depression should not be dismissed. A higher impact in social relationships $(p<0.01)$ due to the presence of depression indexes was also found in a study in Spain (PIMENTEL; AFONSO; PEREIRA, 2011).
An investigation in Portugal, with institutionalized elders, found a significant and negative correlation $(\mathrm{p}<0.01)$ between depressive symptoms and satisfaction levels, suggesting that social support can soften the depressive symptoms among elders (PEREIRA et al., 2006). Thus, it is a responsibility of the health team to investigate the elders' support network, and maximize it.

A previous study showed that social participation (specific social aspects of the elder population) was a predictor of general QoL among active female elders (PEREIRA et al., 2006). According to it, Physical and Environment domains were the ones that better predicted the general QoL - the same result found in this study. Arnold et al. (2004), on the other hand, conducted a study with elders with different health conditions (individuals in good health conditions and victims of conditions such as hypertension, diabetes, osteomuscular problems, among others) and found the Psychological domain to be the predictor for the general QoL and health perception. Therefore, it can be noticed that the level of physical activity and the health condition are important mediators of the association between health perception and the specific aspects of the QoL.

In addition, another dimension which should be considered in the health of the elder is the environment. According to the World Health Organization (2001), the environment in which the elder is inserted can determine their dependence or independence. Elders who live in unsafe environments are less prone to leave their residence alone, and therefore, more susceptible to isolation and depression, as well as to having more mobility problems and worst physical states, which influences the QoL and their health perception. These evidences have been confirmed by other studies (FARENZENA et al., 2007; PASKULIN et al., 2009), pointing out the importance of environmental aspects, especially those related to the economic situation (for instance, to the quality of the environment where they live, their safety and access to health care and leisure), which are all associated to the perception of health and QoL among elders.

Having a partner generated a better QoL perception in the social domain. A study conducted in a municipality in the countryside of the state of Minas Gerais has found that, among the elderly, those without a partner in the urban area were older and had lower educational levels. In the WHOQOLBREF, the lowest QoL score was in the environment, in both groups; in the WHOQOLOLD, the lowest one was in the autonomy facet. 
The elders without partners presented significantly lower scores in the social relation domains and in the intimacy facet (MARCHIORI; DIAS; TAVARES, 2013).

Regarding the facets, the less active elders had the lowest results in autonomy. A less autonomous elder is a less active elder, and that interferes in their choices. That can influence quotidian tasks, such as: the clothes they are going to wear, where they go and what they eat. In this sense, it is paramount to stimulate their potential, encouraging elders to enjoy their rights (FLECK; CHACHAMOVICH; TRENTINI, 2006).

In the death and dying facet, those among 60 and 79 years of age and the catholic and evangelic had the highest scores, as opposed to a research conducted in Turkey. It can be inferred that the presence of comorbidities can have a negative effect in issues related to death, considering its impact on the daily life of the elder. In this sense, it is relevant that health services develop strategies to monitor the health conditions of elders, especially directed at those who are victims of comorbidities, as to minimize the impact of those on their QoL. Also, the elders should be monitored regarding possible sensory losses due to comorbidities and activities that favor reflections concerning the finiteness of life (BILGILI; ARPACI, 2016).

The impact of depression indexes on personal relations, an aspect evaluated in the intimacy facet, indicates the need to encourage such relations. It was found that the elders who do not have a partner and, in the sensory function facet, those between 60 and 79 years of age, are the most negatively affected by this dimension. It is necessary to investigate whether the frail relationships of the elders could be contributing to their depression index. The strengthening of this network is believed to favor the minimization of depressive symptoms (RODRIGUES et al., 2017)

Most elders in the research were women, catholic, with 4 years or more of formal education, had partners, an income of up to 3 minimum wages, a sexually inactive life, and were retired.
Regarding the WHOQOL-Bref, females had a lower score in the psychological and environment domains. Statistically significant results were found between educational levels and the psychological and social domains. There was an association between income and the physical domain, as well as an association between all the domains of the WHOQOL-Bref and a sexually active life. An association was found between less active elders and the physical domain, as well as another between the catholic or protestant religion and the facet death or dying. A lower educational level was associated to the sensory function. Not having a partner was associated to the intimacy facet, while the lack of a sexual life had a significant connection to the facets "past, present and future activities", "social participation", "intimacy", and "sensory function".

A linear regression analysis, adapted to the predictors, the WHOQOL-Bref domains and the WHOQOL-Old facets, found a positive and light or moderate association between sexual life and the physical, social, and environmental domains, and the past, present and future activities facet. The educational level variable, on the other hand, had a positive and light association with the psychological domain, whereas the variable occupation had a negative and light association with the death and dying facet.

The association between the domains of the WHOQOL-Bref and sexual activity denotes that sexual inactivity in old age is associated with worse perceptions of QoL. To this end, it is suggested the realization of new studies that aim to search for the same variables by gender and age group.

The results found show an important social impact regarding the studied population, making it clear that public policies should be created and executed as to offer subsidies for actions which are specifically targeted at the QoL of elders. The family should also be involved in this process, encouraging elders to socialize more, as well as aiding them when necessary.

RESUMO: Este estudo teve como objetivo avaliar os preditores sociais e econômicos, bem como o comportamento social e sua influência na qualidade de vida dos idosos que utilizam a rede de Atenção Primária à Saúde de Uberaba, Minas Gerais. Métodos: Estudo descritivo, exploratório, transversal e quantitativo, realizado com 248 pessoas de 60 anos ou mais, entre novembro de 2016 a maio de 2017. Foi aplicado um questionário estruturado para avaliar os dados sociodemográficos, condições de saúde e hábitos de vida, bem como o WHOQOL-Bref e o WHOQOL-Old. A análise foi realizada através de freqüências relativas e teste t, bem como regressão linear múltipla foram utilizadas para associar variáveis. O estudo foi aprovado pelo Comitê de Ética em Pesquisa com Seres Humanos da Universidade Federal do Triângulo Mineiro (CEP / UFTM). Resultados: A maioria dos idosos eram mulheres, católicas, com 4 anos ou mais de educação formal, 
tinham parceiros, uma vida sexualmente inativa e eram aposentadas. A análise de regressão linear, encontrou uma associação positiva leve ou moderada entre a vida sexual e os domínios físico, social e ambiental, e facetas de atividades passadas, presentes e futuras. A variável nível educacional teve uma associação positiva e leve com o domínio psicológico, enquanto que a variável ocupação teve uma associação negativa e leve com a faceta de morte e morrer.

Conclusões: Os resultados encontrados mostram um impacto social importante em relação à população estudada, deixando claro que as políticas públicas devem ser criadas e executadas de forma a oferecer subsídios para ações especificamente voltadas para a QV dos idosos.

PALAVRAS-CHAVE: Qualidade de vida. Idoso. Saúde do Idoso. Atenção Primária à Saúde.

\section{REFERENCES}

ALMEIDA-BRASIL, C.C.; et al . Quality of life and associated characteristics: application of WHOQOLBREF in the context of Primary Health Care. Ciênc. saúde coletiva, Rio de Janeiro, v. 22, n. 5, p. 17051716, May 2017. Available from: http://dx.doi.org/10.1590/1413-81232017225.20362015. Access in: 18 aug 2017.

ARNOLD R, RANCHOR AV, SANDERMAN R, KEMPEN GI, ORMEL J, SUURMEIJER TP. The relative contribution of domains of quality of life to overall quality of life for different chronic diseases. Qual Life Res, v.13, n.5, p.883-96, 2004.

BILGILI, N.; ARPACI, F. Quality of life of older adults in Turkey. Arch Gerontol Geriatr [Internet]. v.59, n.2, p.415-21, 2014. Available from: doi: 10.1016/j.archger.2014.07.005. Access in: 18 aug 2017.

COELHO, D.N.P.; DANTER, D.V.; SANTANA, R.F.; SANTO, F.H.E. Percepção de mulheres idosas sobre sexualidade: implicações de gênero e no cuidado de enfermagem. Rev. Rene , v.11, n.4, p.163-173, 2010. Available from: http://www.redalyc.org/articulo.oa?id=324027972017. Access in: 18 aug 2017.

DOS SANTOS, O.F.J.; et al. Qualidade de vida de idosos atendidos na Estratégia Saúde da Família. Revista de Pesquisa Cuidado é Fundamental Online, v. 7, n. 1, p. 2021-2033, 2015. Available from: http://www.redalyc.org/articulo.oa?id=505750945030. Access in: 18 aug 2017.

FARENZENA, W.P.; ARGIMON, I.L.; MORIGUCHI, E.; PORTUGUEZ, M.W. Qualidade de vida em um grupo de idosos de Veranópolis. Rev Kairós, v.10, n.2, p.225-43, 2007.

FERREIRA, K.S.; SILVA, M.G.; CHEREM, T.M.D.A.; ARAÚJO, C.L.O. Percepção dos idosos perante o sexo na idade avançada. Rev. bras. geriatr. Gerontol, v.3, n.4, p.182-8, 2009.

FERREIRA, M.C.G.; et al . Representações sociais de idosos sobre qualidade de vida. Rev. Bras. Enferm., Brasília, v. 70, n. 4, p. 806-813, ago. 2017 . Available from: http://dx.doi.org/10.1590/0034-7167-20170097. Access in: 18 aug 2017.

FLECK, M.P.; CHACHAMOVICH, E.; TRENTINI, C. Development and validation of the Portuguese version of the WHOQOL-OLD module. Revista de Saúde Pública São Paulo, v. 40, n. 5, p. 785-91, 2006. Available from: http://dx.doi.org/10.1590/S0034-89102006000600007.. Access in: 18 aug 2017.

FLECK, M.P.A. O instrumento de avaliação de qualidade de vida da Organização Mundial da Saúde (WHOQOL-100): características e perspectivas. Ciênc. saúde coletiva, Rio de Janeiro , v. 5, n. 1, p. 33-38, 2000 . Available from: http://dx.doi.org/10.1590/S1413-81232000000100004. Access in: 18 aug 2017.

GAMPEL, D.; KARSCH, U.M.; FERREIRA, L.P. Percepção de voz e qualidade de vida em idosos professores e não professores. Ciênc. saúde coletiva, Rio de Janeiro, v. 15, n. 6, p. 2907-16, 2010 . Available from: http://dx.doi.org/10.1590/S1413-81232010000600028. Access in: 18 aug 2017. 
LIMA-COSTA, M.F.; et al . Desigualdade social e saúde entre idosos brasileiros: um estudo baseado na Pesquisa Nacional por Amostra de Domicílios. Cad. Saúde Pública, v. 19, n. 3, p. 745-757, 2003 . Available from http://dx.doi.org/10.1590/S0102-311X2003000300007. Access in: 18 aug 2017.

LUCAS-CARRASCO, R.; LAIDLAW, K.; POWER, M.J. Suitability of the WHOQOL-BREF and WHOQOLOLD for Spanish older adults. Aging Ment Health [Internet]. v. 15, n.5, p.595-604, 2011. Available from: http://www.tandfonline.com/doi/abs/10.1080/13607863.2010.548054. Access in: 18 aug 2017.

MARCHIORI, G.F.; DIAS, F.A.; TAVARES, D.M.S. Qualidade de vida entre idosos com e sem companheiro. Rev enferm UFPE on line., Recife, v.7, n.4, p.1098-106, 2013. Available from: DOI: 10.5205/r euol.318826334-1-LE.0704201304. Access in: 18 aug 2017.

ORGANIZAÇÃO MUNDIAL DE SAÚDE (OMS). Saúde e envelhecimento: Um documento para o debate: Versão Preliminar. Madrid: Instituto de Migração e Serviços Sociais; 2001.

PASKULIN, L.; VIANNA, L.; MOLZAHN, A.E. Factors associated with quality of life of Brazilian older adults. Int Nurs Rev, v.56, n.1, p.109-15, 2009. Available from: doi:10.1111/j.1466-7657.2008.00671.x. Access in: 18 aug 2017.

PASKULIN, L.M.G.; et al. Percepção de pessoas idosas sobre qualidade de vida. Acta paul. enferm., São Paulo, v. 23, n. 1, p. 101-7, 2010. Available from: http://dx.doi.org/10.1590/S0103-21002010000100016. Access in: 18 aug 2017.

PEREIRA, R.J.; et al . Contribuição dos domínios físico, social, psicológico e ambiental para a qualidade de vida global de idosos. Rev. psiquiatr. Rio Gd. Sul, Porto Alegre, v. 28, n. 1, p. 27-38, 2006 . Available from: http://dx.doi.org/10.1590/S0101-81082006000100005. Access in: 18 aug 2017.

PILGER, C. Estudo correlacional entre bem-estar espiritual, religiosidade, enfrentamento religioso e espiritual e qualidade de vida de idosos em tratamento hemodialítico. Horizonte, v. 14, n. 41, p. 202-205, 2016.

PIMENTEL, A.F.; AFONSO, R.M.; PEREIRA, H. Depression and support in old age. Psicol saúde doenç [Internet]. v. 13, n. 2, p. 311-27, 2012. Available from: http://www.scielo.mec.pt/pdf/psd/v13n2/v13n2a13.pdf. Access in: 18 aug 2017.

Policy Summary of The Canadian Medical Association. Health and Health Care for an Aging Population [Internet]. 1st ed. Canadá: The Canadian Medical Association; 2013. Available in:

https://www.cma.ca/Assets/assets-library/document/en/advocacy/policy-

research/CMA_Policy_Health_and_Health_Care_for_an_Aging-Population_PD14-03-e.pdf Access in: 18 aug 2017.

RODRIGUES, L.R.; TAVARES, D.S.; DIAS, F.A. et al. Qualidade de vida de idosos comunitários e fatores associados. Rev enferm UFPE on line., Recife, v. 11 (Supl. 3), p.1430-8, 2017. Available from: 10.5205/reuol.10263-91568-1-RV.1103sup201715. Access in: 18 aug 2017.

SANTOS, A.S.; IKEGAMI, E.M.; ALMEIDA, J.R.; PAIVA, M.H.P.; SILVEIRA, R.E. Physical exercise and functional capacity in elderly from the South Triangle Health Regional - Minas Gerais state, Brazil: evaluation by gender. Biosci. J., v.32, n.3, p. 764-72, 2016. Available in: http://sci-hub.cc/10.14393/J-v32n3a2016-30420 Access in: 18 aug 2017.

SANTOS, N.C.; ABDALA, G.A. Religiosidade e qualidade de vida relacionada à saúde dos idosos em um município na Bahia, Brasil. Rev. bras. geriatr. gerontol., Rio de Janeiro, v. 17, n. 4, p. 795-805, 2014. Available from: http://dx.doi.org/10.1590/1809-9823.2014.13166. Access in: 18 aug 2017. 
SANTOS, P.; et al. Atividades no lazer e qualidade de vida de idosos de um programa de extensão universitária em Florianópolis (SC). Revista Brasileira de Atividade Física \& Saúde, v. 19, n. 4, p. 494, 2014. Available from: http://sci-hub.cc/10.12820/rbafs.v.19n4p494. Access in: 18 aug 2017.

SILVA, R.J.S.; et al. Prevalência e fatores associados à percepção negativa da saúde em pessoas idosas no Brasil. Rev. bras. epidemiol., São Paulo, v. 15, n. 1, p. 49-62, 2012. Available from: http://dx.doi.org/10.1590/S1415-790X2012000100005. Access in: 18 aug 2017.

SILVEIRA, R.E.; MENDONÇA, F.T.N.F.; SANTOS, A.S.; FILIPE, E.M.V. Estratégias de educação em saúde para idosos: experiências e desafíos. Cultura de los Cuidados (Edición digital), v.19, n.42, p.154-62, 2015. Available in: http://dx.doi.org/10.14198/cuid.2015.42.14 Access in: 18 aug 2017.

TAVARES, Darlene Mara dos Santos; DIAS, Flavia Aparecida. Functional capactiy, morbidities and quality of life of the elderly. Texto contexto - enferm., v. 21, n. 1, p. 112-120, 2012. Available from: http://dx.doi.org/10.1590/S0104-07072012000100013. Access in: 18 aug 2017. 